\title{
In vitro folate supplementation alleviates oxidative stress, mitochondria-associated death signalling and apoptosis induced by 7-ketocholesterol
}

\author{
R.-F. S. Huang*, H.-C. Yaong, S.-C. Chen and Y.-F. Lu \\ Department of Nutrition and Food Sciences, Fu-Jen University, Hsin-Chuang, Taiwan, Republic of China
}

(Received 9 January 2004 - Revised 8 June 2004 - Accepted 13 July 2004)

Folate has recently been proposed as a new antioxidant. Folate supplementation may have a protective effect in counteracting oxidantinduced apoptotic damage. The present studies were undertaken to examine whether there is a direct link between folate levels, antioxidant capability and reduced apoptotic damage. Using an in vitro cellular model of 7-ketocholesterol (KC)-induced apoptosis, U937 cells were pre-cultured with a folate-deficient medium supplemented with various levels of folate $(2-1500 \mu \mathrm{mol} / \mathrm{l})$ before treatment with 7 -KC. Apoptotic markers, mitochondria-associated death signals and levels of reactive oxygen species were assayed. After treatment with 7$\mathrm{KC}$ for $30 \mathrm{~h}$, low and high levels of folate supplementation significantly $(P<0.05)$ reduced nuclear DNA loss. Only high levels of folate supplementation $(>1000 \mu \mathrm{mol} / \mathrm{l})$ were effective in counteracting 7-KC-promoted apoptotic membrane phosphatidylserine exposure and DNA laddering. The attenuation of 7-KC-induced apoptotic damage by high-dose folate supplementation coincided with a partial normalization of mitochondria membrane potential dissipation, a suppression of cytochrome $c$ release and an inhibition of procaspase 3 activation. The prevention of mitochondrial dysfunctions and apoptotic processes was associated with antioxidant actions of high-dose folate by a marked scavenging of intracellular superoxide. Collectively, our present results demonstrate that in vitro folate supplementation exerts differentially protective effects against 7-KC-induced damage. High-dose supplementation alleviates oxidative stress, mitochondria-associated death signalling and apoptosis induced by $7-\mathrm{KC}$. However, the in vivo relevance is not clear and requires further study.

Folate supplementation: Antioxidant: Apoptosis: Mitochondria-associated death signalling: 7-Ketocholesterol

It has recently been proposed that folate scavenges peroxyl radicals, azide radicals and hydroxyl radicals in an in vitro radical reaction model system (Joshi et al. 2001). However, the antioxidant action of folate against cellular damage is not fully understood. Huang et al. (2001) reported that folate depletion accompanied by elevated homocysteine concentrations was correlated with increased lipid peroxidation in rat livers. Numerous investigations have shown that folate deficiency promoted $\mathrm{H}_{2} \mathrm{O}_{2}$ generation and lipid peroxidation in HepG2 cells (Chen et al. 2001; Chern et al. 2001). In human subjects, increased folate intake was found to improve endothelial function in patients with coronary artery disease (Doshi et al. 2001). Reduction of intracellular endothelial superoxide may have contributed to the effect. These studies raise the possibility that folate supplementation may protect cells against oxidative damage, yet a direct link has not been established.

Generation of reactive oxygen species can activate apoptosis, a programmed cell death (Palmer \& Paulson, 1997; Chandra et al. 2000). Apoptotic damage in cells is characterized by chromatin condensation, nucleosomal DNA fragmentation and membrane phosphatidylserine translocation (Kroemer et al. 1995; Granville et al. 1998). Although the mechanisms by which reactive oxygen species induce apoptosis are not fully defined, it has been suggested that mitochondria play a central role (Kroemer et al. 1997; Bernardi et al. 2001). In the oxidant-promoted apoptosis, the depolarization of mitochondrial membrane potential has been attributed to the mitochondrial release of proapoptotic proteins such as cytochrome $c$, which activates the apoptotic executor of caspase 3 to initiate apoptotic DNA damage or membrane disorder (Li et al. 1997; Zamzami \& Kroemer, 2001; Lim et al. 2002). These oxidative apoptotic insults may play a pivotal role in atherosclerosis, because appreciable amounts of apoptotic cells are evident in human atheromatous lesions (Han et al. 1995; Isner et al. 1995). 7-Ketocholesterol (KC), one of the prominently oxidized cholesterols and the most abundantly formed oxysterol in human atherosclerotic plaque (Brown et al. 1997; Garcia-Cruset et al. 1999), has been shown to induce apoptosis in endothelial cells (Lizard et al. 1997, 1999), smooth muscle cells (Nishio et al. 1996; Nishio \& Watanabe, 1996) and monocytic cells (Aupeix et al. 1995; O'Callaghan et al. 2001). The loss of mitochondrial transmembrane potential and the cytosolic release of cytochrome $c$ occurred during 7-KC-induced apoptosis (Lizard et al. 2000). Antioxidants such as glutathione and vitamin $\mathrm{E}$ can prevent 7 -KC-induced apoptosis 
by the disruption of mitochondrial transmembrane potential and cytochrome $c$ release (Lizard et al. 2000).

Folate deficiency was shown previously to induce apoptotic damage in several cell lines (James et al. 1994; Koury et al. 1997; Huang et al. 1999) and in animals (James et al. 1997; Craciunescu et al. 2004). The underlying mechanisms relating to the antioxidant capability of folate and its role in the signalling of mitochondria-associated apoptotic death are largely unknown. 7-KC-induced apoptosis provides us with a unique model to investigate whether there is a direct link between folate levels, antioxidant capability, mitochondria-associated death signalling and reduced apoptotic damage. U937 cells were chosen as an in vitro cellular model, because it is one of the most commonly used cell lines to study the molecular mechanisms of oxysterol-induced apoptosis (Lizard et al. 1998, 2000). U937 cells are also frequently used as macrophage reference models that are sensitive to oxysterols toxicity in the same range of concentrations observed in other vascular cells (Lizard et al. 1996, 1997, 1998). We added various levels of folate to folate-deficient (FD) medium and measured apoptotic variables, mitochondrial transmembrane potential, cytochrome $c$ release, procaspase 3 activation and intracellular reactive oxygen species levels in U937 cells in the presence or absence of 7-KC.

\section{Materials and methods}

\section{Materials}

7-KC, folate (pteroylmonoglutamic acid), rodamine 123, propidium iodide (PI), 2' $2^{\prime}$-dichlorofluorescin diacetate and hydroethidine were purchased from Sigma Chemical Co. (St Louis, MO, USA). Fetal bovine serum was purchased from HyClone Laboratories (Logan, UT, USA). Complete FD Roswell Park Memorial Institute 1640 medium and antibiotics were purchased from GIBCO Laboratories (Grand Island, NY, USA). The rabbit antihuman CPP32 and cytochrome $c$ antibody were from BD Biosciences (San Jose, CA, USA) and R\&D Systems (Minneapolis, MN, USA). Multimers of $100 \mathrm{bp}$ DNA were from Pharmacia Biotech (Piscataway, NJ, USA).

\section{Cell culture}

U937 cells, a human promonocytic leukaemia cell line, were purchased from the cell bank of NRIH (Taipei, Taiwan; CCRC 60027). U937 cells were regularly maintained in complete Roswell Park Memorial Institute 1640 medium supplemented with heat-inactivated fetal bovine serum $(100 \mathrm{ml} / \mathrm{l})$ and antibiotics (2000 Upenicillin/1 and $20 \mathrm{mg}$ streptomycin/l). Cells were maintained in suspension cultures in a humidified $5 \% \mathrm{CO}_{2}$ atmosphere at $37^{\circ} \mathrm{C}$. Cellular viability was determined by Trypan Blue exclusion.

\section{Experimental treatments}

For all experiments, a 7-KC stock solution was prepared according to the methods of Lizard et al. (2000). Briefly, $800 \mu \mathrm{g} 7-\mathrm{KC}$ was dissolved in $50 \mu \mathrm{l}$ absolute ethanol and $950 \mu \mathrm{l}$ FD medium was added. The solution was then sonicated. The ethanol level in culture medium of final concentration $40 \mu \mathrm{g} 7-\mathrm{KC} / \mathrm{ml}$ had no effect on cell viability when it was measured with Trypan Blue. A stock solution of folate was prepared at $10 \mathrm{mmol} / \mathrm{l}$ by dissolving $44 \mathrm{mg}$ folate in $10 \mathrm{ml} \mathrm{NaHCO}_{3}(10 \mathrm{~g} / \mathrm{l})$ solution. To make up media with various levels of folate, folate stock was added to FD medium and the $\mathrm{pH}$ was adjusted to 7.4 before sterilization by filtration. All stock solutions were freshly prepared before experiments.

The doubling time for U937 cells is $26 \pm 2 \mathrm{~h}$. Viability and growth rate of cells were frequently checked using Trypan Blue exclusion. Cells in the log growth phase were sub-cultured into various sets of plates for conducting each experiment. U937 cells were pre-incubated in FD medium with various levels of folate for $6 \mathrm{~h}$ and then treated with 7-KC to induce apoptosis. Cultures without 7-KC treatment at the designated experimental time points were used as additional controls. After the treatments were terminated, cells were harvested for the assay.

\section{Analysis of apoptotic cells with membrane phosphatidylserine exposure}

The Annexin-V-Fluos kit (Roche Diagnostics, Mannheim, Germany) was used to measure the apoptotic cells with membrane phosphatidylserine translocation. Cells were suspended in incubation buffer that contained $1 \mathrm{mg} \mathrm{PI} / \mathrm{l}$ and a 1:50 dilution of Annexin-V-Fluos labelling solution. The mixed solution was incubated for $15 \mathrm{~min}$ on ice, and green Annexin-V and red PI fluorescence intensities were analysed on a Coulter EPICS XL-MCL flow cytometer (Coulter Corporation, Miami, FL, USA). Cells with Annexin-V-positive and PI-negative fluorescence were defined as apoptotic cells. Cells with Annexin-V-negative and PI-positive fluorescence (PI permeable) were defined as necrotic cells.

\section{Analysis of apoptotic cells with hypodiploid DNA contents}

Cells were fixed in ice-cold ethanol. RNase A $(500 \mathrm{mg} / \mathrm{l})$ and Triton $(5 \mathrm{~g} / \mathrm{l})$ were added to samples at $37^{\circ} \mathrm{C}$ for further incubation for $60 \mathrm{~min}$. Cells were then incubated with PI $(50 \mathrm{mg}$ / 1) for $20 \mathrm{~min}$ at $37^{\circ} \mathrm{C}$. After centrifugation, cellular DNA (red fluorescence) in 10000 cells was analysed on a flow cytometer with the System II software program (Coulter, Corporation). The percentage of cells in different cell cycle phases was estimated from PI histograms using WinMDI 2.8 software (Coulter Corporation). Hypodiploid cells, i.e. those with lower G0/G1 DNA contents, were defined as apoptotic cells, as described by Endresen et al. (1994).

\section{Agarose electrophoresis of DNA fragmentation}

As described by Huang et al. (2002), $3 \times 10^{6}$ cells at each indicated time point were harvested and suspended in icecold lysis buffer $(100 \mathrm{mmol} \mathrm{NaCl} / 1,10 \mathrm{mmol}$ Tris- $\mathrm{HCl} / \mathrm{l}$, $25 \mathrm{mmol}$ EDTA/l, $5 \mathrm{~g} \mathrm{SDS} / 1$ and $0.3 \mathrm{~g}$ proteinase $\mathrm{K} / \mathrm{l}$ ) for $15 \mathrm{~h}$ in a water-bath at $50^{\circ} \mathrm{C}$. The standard phenol-chloroform-isoamyl alcohol (25:24:1, by vol.) method was used to remove protein and extract DNA. RNA was digested with $1 \mathrm{mg}$ ribonuclease $\mathrm{A} / 1$ for $1 \mathrm{~h}$ at $37^{\circ} \mathrm{C}$. DNA fragments 
were electrophoresed on an agarose $(20 \mathrm{~g} / \mathrm{l})$ mini-gel at $100 \mathrm{~V}$ for $40 \mathrm{~min}$ and visualized with ethidium bromide staining under UV illumination.

\section{Quantification of depolarized cells with mitochondrial membrane potential dissipation}

Rodamine 123 has been widely used as a flow cytometric probe for mitochondrial membrane potential (Juan et al. 1994). Rodamine 123 was added directly to the culture medium $(5 \mathrm{mg} / \mathrm{l})$ and incubated for $30 \mathrm{~min}$ at $37^{\circ} \mathrm{C}$. After centrifugation, cells were analysed with a flow cytometer (excitation $488 \mathrm{~nm}$, emission $625 \mathrm{~nm}$ ). Dead cells and debris were excluded from the analysis by electronic gating of forward- and side-scatter measurement.

\section{Determination of intracellular reactive oxygen species levels}

Intracellular reactive oxygen species were assayed using the fluorescent dyes $2^{\prime}, 7^{\prime}$-dichlorofluorescin diacetate and hydroethidine (Robinson et al. 1994). Intracellular $\mathrm{H}_{2} \mathrm{O}_{2}$ or NO oxidizes $2^{\prime}, 7^{\prime}$-dichlorofluorescin to the highly fluorescent compound. Hydroethidine oxidation is particularly sensitive to superoxide anions. Thirty minutes before 7-KC treatment was terminated, $2^{\prime}, 7^{\prime}$-dichlorofluorescin diacetate $(5 \mu \mathrm{mol} / \mathrm{l})$ or hydroethidine $(5 \mu \mathrm{mol} / \mathrm{l})$ was added into cultured cells. At each indicated time point, cells were harvested and the fluorescence intensity of intracellular dichlorofluorescin (emission $530 \mathrm{~nm}$ ) or hydroethidine (emission $585 \mathrm{~nm}$ ) was monitored on a flow cytometer (Coulter Corporation).

\section{Subcellular fractionation and Western blot analysis}

Cytochrome $c$ release into the cytosol and degradation of procaspase 3 were investigated by Western blot analysis. The analysis of cytochrome $c$ release to cytosol was performed according to the method of Lizard et al. (2000). In brief, cells were suspended in lysis buffer $(20 \mathrm{mmol}$ HEPES-KOH/l (pH 7.5), $10 \mathrm{mmol} \mathrm{KCl} / 1,1.5 \mathrm{mmol} \mathrm{MgCl} /$ 1, $1 \mathrm{mmol}$ EDTA/l, $1 \mathrm{mmol}$ sodium ethylene glycol tetraacetic acid/l, $1 \mathrm{mmol}$ dithiothreitol $/ 1,250 \mathrm{mmol}$ sucrose/l and a mixture of protease inhibitors) and were homogenized by successive passages through a 27-guage fine needle. By centrifuging the homogenate at $1000 \mathrm{~g}$ at $4^{\circ} \mathrm{C}$ for $10 \mathrm{~min}$, the resulting supernatant fraction was subjected to $15500 \mathrm{~g}$ centrifugation at $4^{\circ} \mathrm{C}$ for $30 \mathrm{~min}$ to generate cytosol. For analysis of procaspase 3 (CPP32), cells were lysed in lysis buffer (50 mmol Tris- $\mathrm{HCl} / \mathrm{l}(\mathrm{pH} 8 \cdot 0), 150 \mathrm{nmol} \mathrm{NaCl} /$ $1,1 \mathrm{~g} \mathrm{SDS} / 1,1 \mathrm{mmol}$ sodium ethylene glycol tetraacetic acid/l, $1 \mathrm{mmol}$ dithiothreitol/1, $250 \mathrm{mmol}$ sucrose/l and a mixture of protease inhibitors) for $30 \mathrm{~min}$ on ice and then centrifuged at $4^{\circ} \mathrm{C}(14000 \mathrm{~g}$ for $15 \mathrm{~min})$. The protein concentration was measured by Bio-Rad assay (Bio-Rad Laboratories, Hercules, CA, USA) with bovine serum albumin as the standard. Proteins $(50 \mu \mathrm{g})$ were incubated in loading buffer, separated by SDS-PAGE, and electroblotted to a polyvinylidine difluoride membrane. Proteins were probed with human monoclonal antibody directed against cytochrome $c$ and caspase 3 (Santa Cruz Biotechnology,
Santa Cruz, CA, USA), followed by peroxidase-labelled anti-mouse antibodies and visualized using an enhanced chemoluminescence detection kit (Amersham International Amersham, Bucks., UK) by autoradiography.

\section{Statistical analysis}

All results were presented as mean values and standard deviations. One-way ANOVA and Duncan's test were used for comparisons among folate-supplemented groups. Statistical significance was set at $P<0 \cdot 05$.

\section{Results}

\section{Dose effects of folate supplementation on} 7-ketocholesterol-induced apoptosis

Previous studies have demonstrated that treatment with $40 \mu \mathrm{g} 7-\mathrm{KC} / \mathrm{ml}$ can induce apoptosis in the U937 cellular model (Lizard et al. 1998, 2000). We measured the dose effects of folate supplementation against apoptotic damage as a function of time after treatment with $40 \mu \mathrm{g}$ $7-\mathrm{KC} / \mathrm{ml}$. The results are shown in Table 1 . In the absence of 7-KC treatment, cells cultured in FD medium did not display apoptosis within the experimental time periods. After $24 \mathrm{~h}$ of treatment with $7-\mathrm{KC}$, the apoptotic cells with hypodiploid DNA content were increased to $18 \%$. Folate supplementation at $100-1500 \mu \mathrm{mol} / \mathrm{l}$ significantly reduced the hypodiploid cellular fractions, with the greatest magnitude of reduction with high-folate supplementation. After $30 \mathrm{~h}$ of treatment with $7-\mathrm{KC}$, pre-incubation of 7-KC-treated cells with media that contained a normal folate level $(2 \mu \mathrm{mol} / \mathrm{l})$ and high folate levels (1000 and $1500 \mu \mathrm{mol} / \mathrm{l})$ significantly reduced $(P<0.05)$ the hypodiploid cellular fractions $(\%)$. Folate at $1500 \mu \mathrm{mol} / \mathrm{l}$ markedly diminished 7-KC-promoted hypodiploid cellular fractions by half. The fraction of apoptotic cells with membrane phosphatidylserine translocation (Annexin-V-positive and PI-negative) was $25 \%$ after $24 \mathrm{~h}$ of $7-\mathrm{KC}$ treatment, and this increased to $49 \%$ after $30 \mathrm{~h}$ of treatment with 7 -KC. Folate supplementation $(2-1500 \mu \mathrm{mol} / \mathrm{l})$ did not affect 7 -KC-induced apoptotic membrane disorder at $24 \mathrm{~h}$, whereas supplementation with $1500 \mu \mathrm{mol}$ folate/l significantly reduced $(P<0 \cdot 05)$ Annexin-V-positive cells (by half) after $30 \mathrm{~h}$ of $7-\mathrm{KC}$ treatment.

The protective effects of folate supplements against apoptotic DNA damage were further confirmed by the results of electrophoretic analysis (Fig. 1). After $30 \mathrm{~h}$ of 7-KC treatment, apoptotic DNA laddering was seen (lane 3 ). Folate supplements at 1000-2000 $\mu \mathrm{mol} / \mathrm{l}$ (lanes 6-8), but not at $2-100 \mu \mathrm{mol} / \mathrm{l}$ (lanes 4 and 5), substantially decreased the 7-KC-induced DNA fragmentation. In the absence of 7-KC treatment, no DNA fragmentation was detected in cells cultured with complete or FD medium (lanes 1 and 2).

\section{Effects of folate supplementation on 7-ketocholesterol- induced mitochondria membrane potential dissipation}

To understand whether the impairment of 7-KC-induced apoptosis by folate might be associated with changes in 
Table 1. Effects of folate supplementation on the percentages of apoptotic cells in the presence or absence of 7-ketocholesterol treatment* (Mean values and standard deviations of three independent experiments in triplicate)

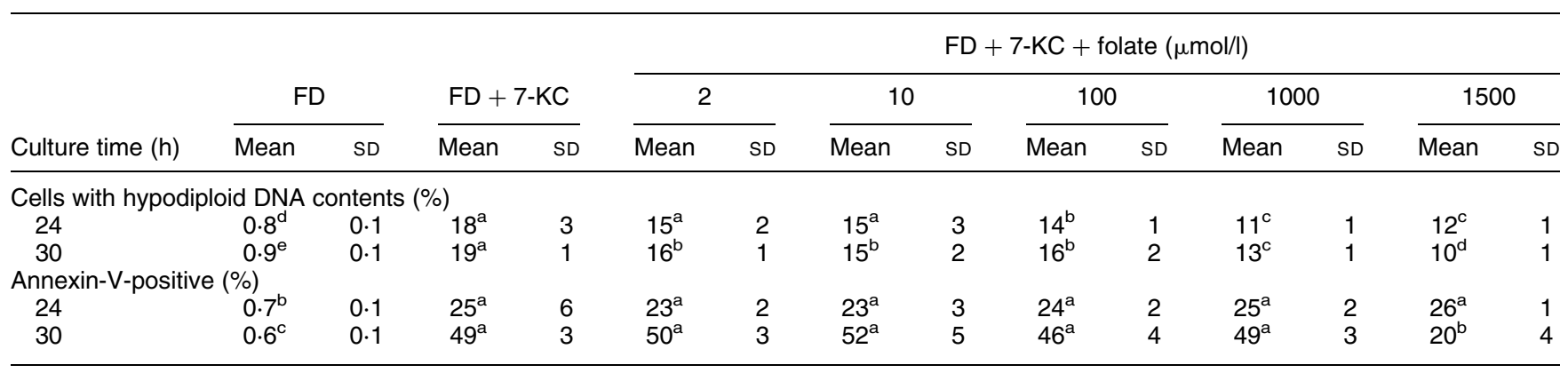

FD, folate deficient; KC, ketocholesterol.

$\mathrm{a}, \mathrm{b}, \mathrm{c}, \mathrm{d}$ Mean values within a row with unlike superscript letters were significantly different $(P<0.05)$

* U937 cells were preincubated with FD medium or FD medium supplemented with various folate levels for $6 \mathrm{~h}$ before treatment with $7-\mathrm{KC}$ (40 $\mu \mathrm{g} / \mathrm{ml}$ ) for the designated time periods. The proportions of apoptotic cells (Annexin-V-positive or hypodiploid cells) were analysed by flow cytometry as described on p. 888 .

mitochondria membrane potential, the percentage of cells with depolarized mitochondria was evaluated using the rodamine 123 probe, by a flow cytometer analysis. Rodamine 123 distribution histograms of cells with FD, FD + 7-KC and $\mathrm{FD}+7-\mathrm{KC}+$ folate treatment are shown in Fig. 2(A)(C). In FD cultures, the percentage of depolarized cells was 10 after $24 \mathrm{~h}$ of 7 -KC treatment and had increased 3 -fold after $30 \mathrm{~h}$ of treatment (Fig. 2(D)). Pre-incubation of cells with 2 or $100 \mu \mathrm{mol}$ folate/l for $6 \mathrm{~h}$ did not affect the $7-\mathrm{KC}$ induced mitochondrial depolarization. Pre-incubation of cells with 1000 and $1500 \mu \mathrm{mol}$ folate/l for $6 \mathrm{~h}$ significantly reduced the percentage of depolarized cells after 24 and $30 \mathrm{~h}$ of treatment with 7-KC. The results shown in Fig. 2(E) further revealed that the protective effects of high-dose folate supplementation were modulated by the length of

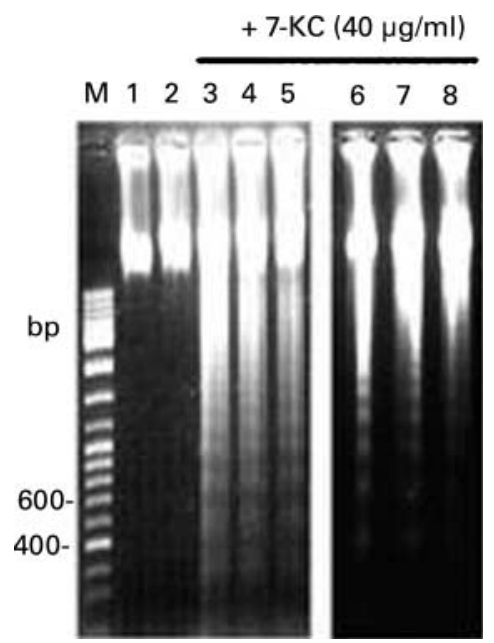

Fig. 1. Effects of folate supplementation on apoptotic DNA laddering in the presence or absence of 7-ketocholesterol (KC) treatment. U937 cells were pre-incubated in folate-deficient medium supplemented with various levels of folate $(2,100,1000,1500$ and $2000 \mu \mathrm{mol} / \mathrm{l})$ for $6 \mathrm{~h}$ before treatment with $7-\mathrm{KC}$. After $30 \mathrm{~h}$ of $7-\mathrm{KC}$ treatment $(40 \mu \mathrm{g} / \mathrm{ml})$, total DNA extracted from U937 cells was analysed by electrophoresis on an agarose $(20 \mathrm{~g} / \mathrm{l})$ mini-gel at $100 \mathrm{~V}$ for $40 \mathrm{~min}$. For details of procedures, see p. 888. Lane M: DNA markers of molecular size at $100 \mathrm{bp}$ multimers. Lane 1: cells not treated with 7-KC in complete medium. Lane 2: cells not treated with 7-KC in folate-deficient medium. Lanes 3-8: cells treated with 7-KC and pre-incubated with folate levels at 0 (lane 3), 2 (lane 4), 100 (lane 5), 1000 (lane 6), 1500 (lane 7) and 2000 (lane 8) $\mu \mathrm{mol} / \mathrm{l}$. pre-incubation time. After $24 \mathrm{~h}$ of treatment with $7-\mathrm{KC}$, high-dose folate did not affect 7-KC-induced mitochondria depolarization if cells were not pre-cultured with folate $(0 \mathrm{~h}$ pre-incubation). The reduction of mitochondria depolarization by high-dose folate supplementation was more remarkable when cells were pre-cultured with folate for $24 \mathrm{~h}$, compared with the cells without folate pre-incubation or with $6 \mathrm{~h}$ folate pre-incubation (Fig. 2(D)).

\section{Effects of folate supplementation on mitochondria-associated signalling}

The apoptotic signalling proteins of cytochrome $c$ release from mitochondria into the cytosol and the cleavage of the inactive precursor (CPP32) were assessed by Western blot analysis. The results are presented in Figs. 3 and 4. After treatment with $7-\mathrm{KC}$ for $24 \mathrm{~h}$, a release of cytochrome $c$ to cytosol was apparent (Fig. 3(B), lane 2), whereas no CPP32 cleavage was observed (Fig. 3(A), lane 2). Folate supplementation at $1500 \mu \mathrm{mol} / \mathrm{l}$ inhibited the 7-KC-promoted cytochrome $c$ release (Fig. 3(B), lane 5). This cytochrome $c$ release in 7-KC-treated cells was followed by the activation of CPP32 after $30 \mathrm{~h}$ of treatment with 7-KC (Fig. 3(A), lane 6). Folate supplementation at 1000 and $1500 \mu \mathrm{mol} / \mathrm{l}$ partially suppressed CPP32 cleavage (Fig. 3(A), lanes 7 and 8). The protective effects of highdose folate against cytochrome $c$ release and caspase 3 activation persisted to $36 \mathrm{~h}$ of $7-\mathrm{KC}$ treatment, as shown in Fig. 4 ((A) and (B), lanes 4 and 5).

\section{Effects of folate supplementation on 7-ketocholesterol- induced reactive oxygen species production}

Table 2 presents results on superoxide anion scavenging by folate supplementation. Compared with 7-KC-untreated cells cultured in FD medium, folate supplementation at 2, 100,1000 and $1500 \mu \mathrm{mol} / \mathrm{l}$ significantly reduced intracellular superoxide levels to $81,75,56$ and $37 \%$. After 7-KC treatment for 12,24 and $30 \mathrm{~h}$, the intracellular superoxide levels of FD cells increased to 2-fold of those in 7-KCuntreated cells. Folate supplementation at $1500 \mu \mathrm{mol} / \mathrm{l}$ had a significantly greater $(P<0.05)$ capability to scavenge 7 -KC-elicited superoxide generation (a $42 \%$ reduction) 
(A)

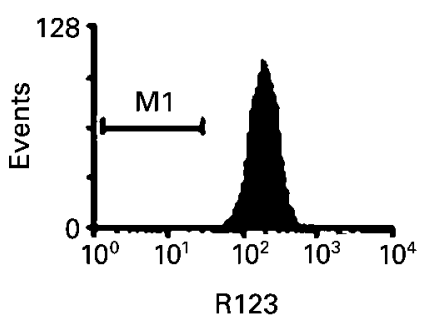

(D)
(B)

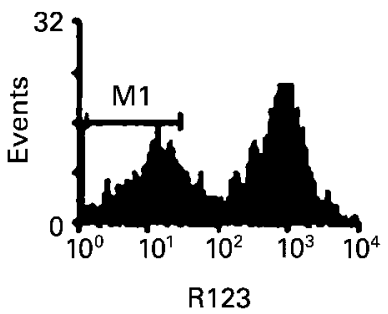

(C)

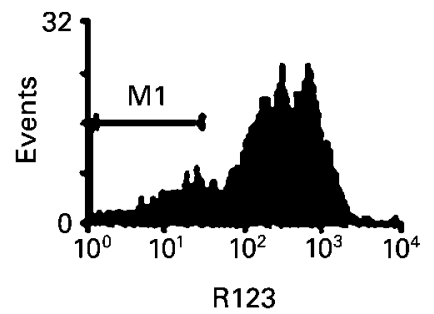

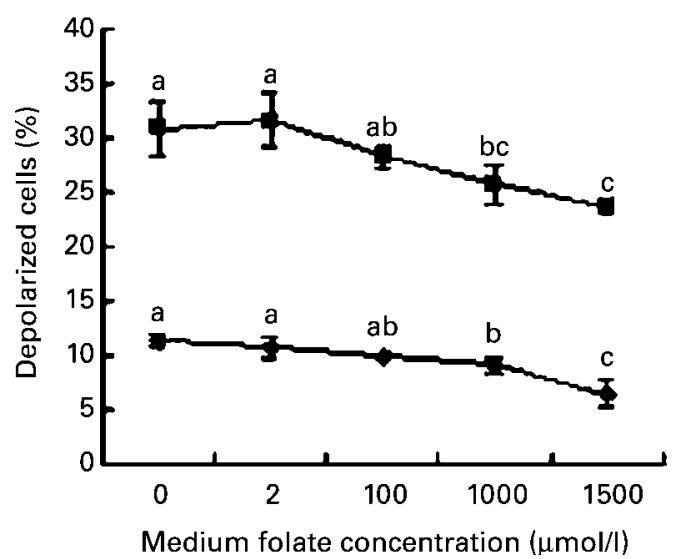

(E)

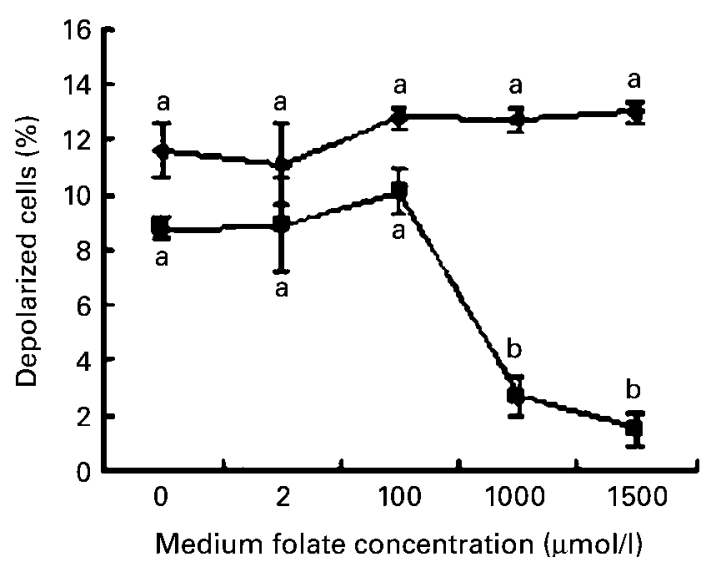

Fig. 2. Changes in mitochondrial membrane potential in cells treated with 7-KC and folate pre-incubation. U937 cells were pre-cultured with various levels of folate for 0,6 and $24 \mathrm{~h}$, treated with 7 -ketocholesterol $(\mathrm{KC} ; 40 \mu \mathrm{g} / \mathrm{ml})$ for the indicated times, and stained with rodamine 123 (R123). The uptake of R123 was analysed by flow cytometry. For details of procedures, see p. 889. (A), (B) and (C), representative histograms of three independent experiments ((A), folate-deficient (FD); (B), FD + 7-KC; (C), FD + 7-KC + 1500 $\mu \mathrm{M}$ folate). Treatment with 7-KC lasted for $30 \mathrm{~h}$. M1 is associated with the proportions of depolarized cells, which are characterized by low values of mitochondrial membrane potential. (D), effects of folate supplementation on the proportions of depolarized cells after $24 \mathrm{~h}(--)$ and $30 \mathrm{~h}(-\mathbf{-})$ treatment with $7-\mathrm{KC}$. Cells were pre-incubated with various levels of folate for $6 \mathrm{~h}$ before $7-\mathrm{KC}$ treatment. $(\mathrm{E})$, effects of the pre-incubation time on the depolarized cell percentage after $24 \mathrm{~h}$ treatment with $7-\mathrm{KC} ;-$ no folate pre-incubation; $-24 \mathrm{~h}$ folate pre-incubation. ${ }^{\mathrm{a}, \mathrm{b}} \mathrm{Mean}$ values with unlike superscript letters on the same line were significantly different: $P<0.05$.

compared with folate supplementation at $2 \mu \mathrm{mol} / \mathrm{l}$ (an $18 \%$ reduction) after $30 \mathrm{~h}$ of treatment with 7 -KC. 7 -KC treatment and folate supplementation did not affect intracellular $\mathrm{H}_{2} \mathrm{O}_{2}$ generation as measured by dichlorofluorescin fluorescence (results not shown).

\section{Discussion}

Our present results confirm previous findings that $7-\mathrm{KC}$ promotes apoptosis in U937 cells (Lizard et al. 1998, 2000; O'Callaghan et al. 2001). Treatment with 7-KC caused a concomitant loss in mitochondria membrane potential, release of cytochrome $c$, and subsequently, the activation of apoptotic executor caspase 3, which was in agreement with the proposed mechanisms in the transmission of death signalling (Lizard et al. 2000). In the absence of 7-KC treatment, however, no apoptotic damage was observed in cells cultured in FD medium during the experimental periods. This is in contrast to previous evidence, which linked folate deficiency to apoptotic promotion in Chinese hamster ovary cells (James et al. 1994), HepG2 cells (Huang et al. 1999) and erythroblasts (Koury et al. 1997). Different cell types and the duration of folate deficiency may be attributable to these observed discrepancies. A longer period of folate deficiency (days or weeks) was frequently used to induce apoptosis, whereas our experimental time period for U937 cells was about $12-36 \mathrm{~h}$.
The present results demonstrate that in vitro folate supplementation protects against 7-KC-triggered apoptotic damage. Supplemented folate at a culture medium dose $(2 \mu \mathrm{mol} / \mathrm{l})$ was sufficient to diminish hypodiploid cellular fractions on 7-KC treatment, whereas only high-dose supplementation was able to ameliorate the apoptotic membrane disorder and DNA fragmentation through suppressing mitochondria-associated death signalling. These results suggest that folate supplementation counteracted the 7-KC-induced apoptotic damage at various intracellular targets and molecular levels. In early literature, the proposed links for folate and apoptosis included decreased thymidylate synthesis (Koury et al. 1997), deoxynucleotide pool imbalance (James et al. 1994, 1997), DNA mismatch repair ( $\mathrm{Gu}$ et al. 2002), elevated homocysteine levels (Duan et al. 2002) and cell cycle-dependent processes (Huang et al. 1999). We found that folate may act as a modulator of mitochondria-associated death signalling to alleviate apoptotic damage, which, to our knowledge, has not been demonstrated previously.

The molecular mechanisms by which high-dose folate could suppress mitochondria-associated death signalling are largely unknown. One of the potential protective mechanisms could be radical scavenging. Reactive oxygen species, such as superoxide and $\mathrm{H}_{2} \mathrm{O}_{2}$, have been reported to be important regulators of mitochondria membrane potential and cytochrome $c$ release in several kinds of 
(A)

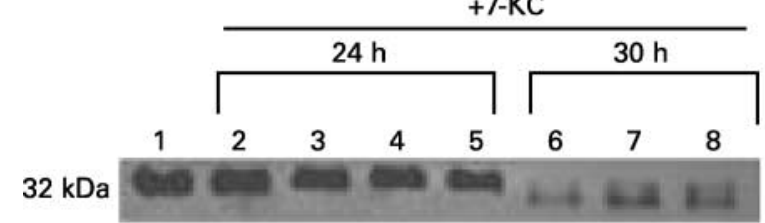

(B)

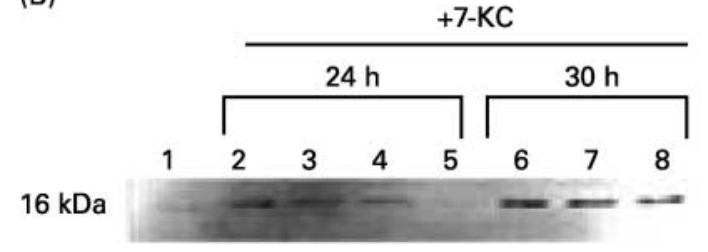

(C)

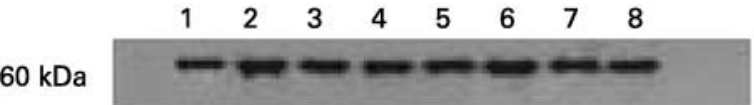

Fig. 3. Modulation of cytochrome $c$ release and procaspase 3 activation by folate supplementation. The cleavage of caspase 3 precursor as procaspase (CPP32, (A)), the release of cytochrome $c$ into the cytosol (B) and $\beta$-actin (C) were investigated by Western blot analysis. U937 cells were pre-incubated in folate-deficient medium supplemented with various levels of folate for $6 \mathrm{~h}$ before treatment with 7-KC. For details of procedures, see. p. 889. Lane 1: cells not treated with 7-ketocholesterol (KC). Lanes 2-5: cells treated with $7-\mathrm{KC}$ for $24 \mathrm{~h}$, and supplemented with folate at concentrations of 0 (lane 2), 2 (lane 3), 1000 (lane 4), and 1500 (lane 5) $\mu \mathrm{mol} / \mathrm{l}$. Lanes 6-7: cells treated with $7-\mathrm{KC}$ for $30 \mathrm{~h}$, and supplemented with folate at concentrations of 0 (lane 6), 1000 (lane 7), and 1500 (lane 8) $\mu \mathrm{mol} / \mathrm{l}$.

oxidative stress-promoted apoptosis (Cai \& Jones, 1998; Stridh et al. 1998; Tada-Oikawa et al. 1999). By scavenging superoxide, antioxidants such as vitamin $\mathrm{E}$ and $\mathrm{N}$-acetylcysteine could reverse mitochondria membrane depolarization and cytochrome $c$ release to the cytosol in 7-KC-treated U937 cells (Lizard et al. 2000). Indeed, we found that high-dose folate supplementation significantly reduced intracellular superoxide levels during the early phase of 7-KC treatment, which coincided with the concomitant reverse of mitochondria dysfunction and apoptotic damage. These results suggest that folate antioxidant
(A)

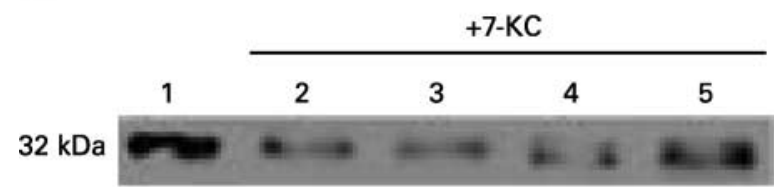

(B)

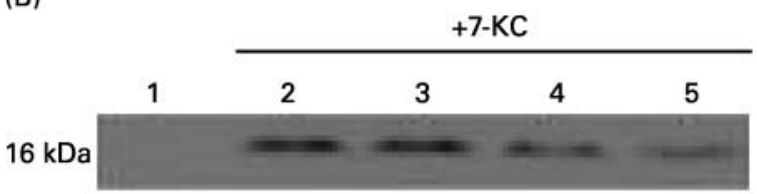

(C)

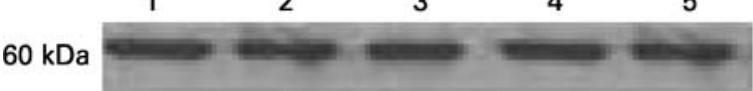

Fig. 4. Effects of folate supplementation on procaspase 3 activation (A), cytochrome $c$ release (B) and $\beta$-actin (C) after $36 \mathrm{~h}$ of treatment with 7-ketocholesterol $(\mathrm{KC})$. Folate pre-incubation is the same as described in Fig. 3. For further details of procedures, see p. 889. Lane 1: cells not treated with 7-KC. Lanes 2-5: cells treated with 7-KC and supplemented with folate at concentrations of 0 (lane 2), 2 (lane 3), 1500 (lane 4) and 2000 (lane 5) $\mu \mathrm{mol} / \mathrm{l}$.

capability, particularly for superoxide scavenging, as has been proposed by previous investigators (Doshi et al. 2001; Huang et al. 2002), can partially account for the impairment in mitochondria-associated death signals.

The anti-apoptotic function by folate may not be limited to its antioxidant property. High-dose folate supplementation may enrich the mitochondria folate pool to strengthen respiratory function, the impairment of which leads to superoxide production and abnormal mitochondrial permeability transition during apoptosis (Cai \& Jones, 1998; Crompton, 1999). This postulation is partially supported by the finding that a lipophilic folate antagonist, at high concentrations, can be accumulated in mitochondria to act as a respiration inhibitor (Sprecher et al. 1995). Alternatively, the suppression of mitochondrial cytochrome $c$ release by folate may be attributable to a downstream effect of folate metabolites through mitochondrial $\mathrm{C}_{1}$ metabolism. 10-Formyl-tetrahydrofolate, a major mitochondria folate coenzyme (Horne

Table 2. Effects of folate supplementation on superoxide production in the presence or absence of 7-ketocholesterol treatment* (Values are means and standard deviations for three independent experiments in triplicate)

\begin{tabular}{|c|c|c|c|c|c|c|c|c|c|c|c|c|c|c|c|c|}
\hline \multirow[b]{3}{*}{ Culture time (h) } & \multirow[b]{3}{*}{ Treatment } & & & & \multicolumn{12}{|c|}{ FD + folate supplementation $(\mu \mathrm{mol} / \mathrm{l})$} \\
\hline & & \multicolumn{3}{|c|}{ FD } & \multicolumn{3}{|c|}{2} & \multicolumn{3}{|c|}{100} & \multicolumn{3}{|c|}{1000} & \multicolumn{3}{|c|}{1500} \\
\hline & & Mean & SD & $\% \dagger$ & Mean & SD & $\% \dagger$ & Mean & SD & $\% \dagger$ & Mean & SD & $\% \dagger$ & Mean & SD & $\% \dagger$ \\
\hline \multicolumn{17}{|c|}{ HE fluorescent intensity } \\
\hline 12 & $-7-\mathrm{KC}$ & $16^{\mathrm{a}}$ & 2 & 100 & $13^{\mathrm{b}}$ & 1 & 81 & $12^{\mathrm{b}}$ & 1 & 75 & $9^{c}$ & 1 & 56 & $6^{\mathrm{d}}$ & 1 & 37 \\
\hline 12 & $+7-\mathrm{KC}$ & $33^{a}$ & 6 & 100 & $35^{\mathrm{a}}$ & 7 & 106 & $26^{\mathrm{b}}$ & 3 & 78 & $22^{\mathrm{b}}$ & 4 & 67 & $19^{b}$ & 2 & 57 \\
\hline 24 & $+7-\mathrm{KC}$ & $34^{\mathrm{a}}$ & 3 & 100 & $27^{\mathrm{b}}$ & 2 & 79 & $25^{\mathrm{b}}$ & 3 & 73 & $26^{\mathrm{b}}$ & 2 & 76 & $19^{\mathrm{C}}$ & 3 & 55 \\
\hline 30 & $+7-\mathrm{KC}$ & $39^{a}$ & 1 & 100 & $32^{b}$ & 5 & 82 & $31^{\mathrm{b}}$ & 3 & 79 & $26^{\mathrm{c}}$ & 1 & 66 & $23^{\mathrm{c}}$ & 2 & 58 \\
\hline
\end{tabular}

FD, folate deficient; HE, hydroethidine; KC, ketocholesterol.

a,b,c,d Mean values within a row with unlike superscript letters were significantly different $(P<0.05)$

* U937 cells were preincubated with FD-medium supplemented by 2, 100,1000 and $1500 \mu \mathrm{mol} / \mathrm{l}$ folate/l for $6 \mathrm{~h}$ before treatment with $7-\mathrm{KC}(40 \mu \mathrm{g} / \mathrm{l})$. At the indicated time points, cells were labelled by HE fluorescent dye for $30 \mathrm{~min}$, harvested, and analysed by flow cytometer. For details of procedures, see p. 889 . †Percentage of FD value. 
et al. 1989), has been shown to support the respiration of rat mitochondria by reducing cytochrome $c$ at the site of respiratory complex IV enzymes (Brookes \& Baggott, 2002). The altered redox state of cytochrome $c$ could modulate its release to the cytosol, and its activation to trigger programmed cell death (Calver et al. 1997; Hancock et al. 2001; Lim et al. 2002). More studies are warranted to elucidate the regulatory role of folate on mitochondria-associated death signalling.

In the current investigation, the effective dose of folate to counteract mitochondria dysfunction was found at $\mathrm{mm}$ levels, which are much greater than those encountered in the human physiological state. It is open to debate whether such in vitro experiments are meaningful in the context of the whole organism. However, it is also generally accepted that metabolic observations in cultured cell lines may not be directly applicable to the multicellular environment. Supraphysiological levels of treatment proved to be necessary to achieve the potential effects on cells in vitro over relatively short experimental time intervals (hours in the present study). We cannot exclude the possibility that, over a longer time course (weeks or months), high dietary folate supplementation could be sufficient to protect against mitochondria dysfunction in vivo. This possibility is supported by the observation that rats fed a high-folate diet had significantly lower percentages of depolarized cells and mitochondrial protein oxidative damage in their livers compared with rats fed a FD diet (Chang, 2004). In human subjects, folic acid supplements at a high dose of $5 \mathrm{mg} / \mathrm{d}$ (more than 10-fold the daily recommended value) for 6 weeks or 4 months significantly improved endothelial dysfunction in patients with coronary artery disease (Title et al. 2000; Doshi et al. 2001). Clinical intervention trials on folate and cancer have further revealed that supplementation with a pharmacological dose of folate $(5-20 \mathrm{mg})$ may have a chemoprotective role (Kim, 1999). Although the mechanisms of long-duration high dietary folate supplementation to protect against human disease are far from understood, our present observations from an in vitro cellular model may provide potential insights into the possible role of high-dose folate in reducing oxidative stress and mitochondria dysfunction.

Given the assumptions and limitations of in vitro studies, the results in the present report suggest that folate supplementation exerts differentially protective effects against 7-KC-induced damage. High-dose supplementation alleviates oxidative stress, mitochondria-associated death signalling and apoptosis induced by $7-\mathrm{KC}$. However, the in vivo relevance is not clear and requires further study.

\section{Acknowledgements}

The authors acknowledge Dr Y.-A. Lee, Department of Life Science, Fu-Jen University, for providing UV illumination and Dr N. S. Shaw, Department of Biotechnology, National Taiwan University, for technical assistance in Western blotting. This study was funded by a grant from the National Science Council, Taiwan, Republic of China (NSC 92-2320-B-030-002).

\section{References}

Aupeix K, Weltin D, Mejia JE, Christ M, Marchal J, Freyssinet JM \& Bischoff P (1995) Oxysterol-induced apoptosis in human monocytic cell lines. Immunobiol 194, 415-428.

Bernardi P, Petronilli V, Lisa FD \& Forte M (2001) A mitochondrial perspective on cell death. Trends Biochem Sci 26, 112-117.

Brookes PS \& Baggott JE (2002) Oxidation of 10-formyltetrahydrofolate to 10-formyldihydrofolate by complex IV of rat mitochondria. Biochem 41, 5633-5636.

Brown AJ, Leong SL, Dean RT \& Jessup W (1997) 7-Hydroperoxycholesterol and its products in oxidized low density lipoprotein and human atherosclerotic plaque. J Lipid Res 38, 1730-1745.

Cai J \& Jones DP (1998) Superoxide in apoptosis. J Biol Chem 273, 11401-11404.

Calver JF, Hill JL \& Dong A (1997) Redox-dependent conformational changes are common structural features of cytochrome $c$ from various species. Arch Biochem Biophys 346, 287-293.

Chandra J, Samali A \& Orrenius S (2000) Triggering and modulation of apoptosis by oxidative stress. Free Radic Biol Med $\mathbf{2 9}$, 323-333.

Chang CM (2004), Effects of folate supplementation on mitochondrial DNA deletion, function and oxidative damage in rat liver, MSc Thesis, Fu-Jen University, Taiwan.

Chen YH, Huang RFS, Wei JS \& Liu TZ (2001) Folate deficiency-mediated down regulation of intracellular glutathione and antioxidant enzymes increases susceptibility of human hepatoma HepG2 cells to various oxidant stress-induced cytotoxicity. J Biomed Lab Sci 13, 52-57.

Chern CL, Huang RFS, Chen YH, Cheng JT \& Liu TZ (2001) Folate deficiency-induced oxidative stress and apoptosis are mediated via homocysteine-dependent overproduction of hydrogen peroxide and enhances activation of NF- $\mathrm{BB}$ in human HepG2 cells. Biomed Pharmacother 55, 434-442.

Craciunescu CN, Brown EC, Mar MH, Albright CD, Nadeau MR $\&$ Zeisel SH (2004) Folic acid deficiency during late gestation decreases progenitor cell proliferation and increases apoptosis in fetal mouse brain. J Nutr 134, 162-166.

Crompton M (1999) The mitochondrial permeability transition pore and its role in cell death. Biochem J 341, 233-249.

Doshi SN, McDowell IFW, Moat SJ, Lang D, Newcombe RG, Kredan MB, Lewis MJ \& Goodfellow J (2001) Folate improves endothelial function in coronary artery disease. An effect mediated by reduction of intracellular superoxide? Arterioscler Thromb Vasc Biol 21, 1196-1202.

Duan W, Ladenheim B, Cutler RG, Kruman II, Cadet JL \& Mattson MP (2002) Dietary folate deficiency and elevated homocysteine levels endanger dopaminergic neuron in models of Parkinson's disease. J Neurochem 80, 101-110.

Endresen PC, Prytz PS, Lysne S \& Aarbakke J (1994) Homocysteine increases the relative number of apoptotic cells and reduces the relative number of apoptotic bodies in HL-60 cells treated with 3-deazaadenosine. J Pharmacol Exp Ther 269, 1245-1253.

Garcia-Cruset S, Carpenter KL, Guardiola F \& Mitchinson MJ (1999) Oxysterols in core of human advanced atherosclerotic lesions. Free Radic Res 30, 341-350.

Granville DJ, Carthy CM, Hunt DWC \& McManus BM (1998) Apoptosis: molecular aspects of cell death and disease. Lab Invest 78, 893-913.

Gu L, Wu J, Qiu L, Jennings CD \& Li GM (2002) Involvement of DNA mismatch repair in folate deficiency-induced apoptosis. $J$ Nutr Biochem 13, 355-363.

Han DKM, Haudenschild CC, Hong MK, Tinkle BT, Leon MB \& Liau G (1995) Evidence for apoptosis in human atherogenesis and in rat injury model. Am J Pathol 147, 267-277.

Hancock JT, Desikan R \& Neill SJ (2001) Does the redox 
status of cytochrome $\mathrm{c}$ act as a fall-safe mechanism in the regulation of programmed cell death? Free Radic Biol Med 31, 697-703.

Horne DW, Patterson D \& Cook RJ (1989) Effect of nitrous oxide inactivation of vitamin $\mathrm{B}_{12}$-dependent methionine synthestase on the subcellular distribution of folate coenzymes in rat liver. Arch Biochem Biophys 270, 729-733.

Huang RFS, Ho YH, Lin HL, Wei JS \& Liu TZ (1999) Folate deficiency induces a cell cycle-specific apoptosis in HepG2 cells. J Nutr 129, 25-31.

Huang RFS, Hsu YC, Lin HL \& Yang FL (2001) Folate depletion and elevated plasma homocysteine promote oxidative stress in rat livers. $J$ Nutr 131, 33-38.

Huang RFS, Huang SM, Lin BS, Hung CY \& Lu HT (2002) $\mathrm{N}$-acetylcysteine, vitamin $\mathrm{C}$ and vitamin $\mathrm{E}$ diminish homocysteine thiolactone-induced apoptosis in human promyeloid HL-60 cells. J Nutr 132, 2151-2155.

Isner JM, Kearney M, Bortman S \& Psseri J (1995) Apoptosis in human atherosclerosis and restenosis. Circulation 91, $2703-2711$.

James SJ, Barbara JM, Basnakian AG, Pogribny IP, Pogribna M \& Muskhelishvili L (1997) Apoptosis and proliferation under conditions of deoxynucleotide pool imbalance in liver of folate/methyl deficient rats. Carcinogenesis 18, 287-293.

James SJ, Basnakian AG \& Miller BJ (1994) In vitro folate deficiency induces deoxynucleotide pool imbalance, apoptosis, and mutagenesis in Chinese hamster ovary cells. Cancer Res 54, 5075-5080.

Joshi R, Adhikari S, Patro BS, Chattopadhyay S \& Mukherjee T (2001) Free radical scavenging behavior of folic acid: evidence for possible antioxidant activity. Free Radic Biol Med 30, 1390-1399.

Juan G, Cavazzoni M, Saez GT \& O'Connor JE (1994) A fast kinetic method for assessing mitochondrial membrane potential in isolated hepatocytes with rhodamine 123 and flow cytometry. Cytometry 15, 335-342.

Kim YI (1999) Folate and carcinogenesis: evidence, mechanisms, and implications. $J$ Nutr Biochem 10, 66-88.

Koury MJ, Horne DW, Brown ZA, Pietenpol JA, Blount BC, Ames BN, Hard R \& Koury ST (1997) Apoptosis of latestage erythroblasts in megaloblastic anemia: association with DNA damage and macrocyte production. Blood 89, 4617-4623.

Kroemer G, Petit P, Zamzami N, Vayssiere J \& Mignotte B (1995) The biochemistry of programmed cell death. FASEB J 9, $1277-1287$.

Kroemer G, Zazami N \& Susin SA (1997) Mitochondrial control of apoptosis. Immunol Today 18, 44-51.

Li P, Nijhawan D, Budihardjo I, Srinivasula SM, Ahmad M, Alnemri ES \& Wang X (1997) Cytochrome $c$ and dATP-dependent formation of Apaf-1/caspase- 9 complex initiates an apoptotic protease cascade. Cell 91, 479-489.

Lim MLR, Lum MG, Hansen TM, Roucou X \& Nagley P (2002) On the release of cytochrome $\mathrm{c}$ from mitochondria during cell death signaling. J Biomed Sci 9, 488-506.

Lizard G, Deckert V, Duberz L, Moisant M, Gambert P \& Lagrost L (1996) Induction of apoptosis in endothelial cells treated with cholesterol oxides. Am J Pathol 148, 1625-1638.
Lizard G, Gueldry S, Sordet O, Monier S, Athias A, Miguet C, Bessede G, Lemaire S, Solary E \& Gambert P (1998) Glutathione is implied in the control of 7-ketocholesterol-induced apoptosis, which is associated with radical oxygen species production. FASEB J 12, 1651-1663.

Lizard G, Miguet C, Bessede G, Monier S, Gueldry S, Neel D \& Gambert P (2000) Impairment with various antioxidants of the loss of mitochondrial transmembrane potential and of the cytosolic release of cytochrome $c$ occurring during 7-ketocholesterol-induced apoptosis. Free Radic Biol Med 28, $743-753$.

Lizard G, Moisant M, Cordelet C, Monier S, Gambert P \& Lagrost L (1997) Induction of similar features of apoptosis in human and bovine vascular endothelial cells treated by 7-ketocholesterol. J Pathol 183, 330-338.

Lizard G, Monier S, Cordelet C, Gesquiere L, Deckert V, Gueldry S, Lagrost L \& Gambert L (1999) Characterization and comparison of the mode of cell death, apoptosis versus necrosis, induced by $7 \alpha$-hydroxycholesterol and 7-ketocholesterol on the cells of the vascular wall. Arterioscler Thromb Vasc Biol 19, 1190-2000.

Nishio E, Arimura S \& Watanabe Y (1996) Oxidized LDL induces apoptosis in cultured smooth muscle cells: a possible role for 7-ketocholesterol. Biochem Biophys Res Commun 223, 413-418.

Nishio E \& Watanabe Y (1996) Oxysterols induced apoptosis in cultured smooth muscle cells through CPP32 protease activation and bcl-2 protein downregulation. Biochem Biophys Res Commun 226, 928-934.

O'Callaghan YC, Woods JA \& O'Brien NM (2001) Comparative study of the cytotoxicity and apoptosis-inducing potential of commonly occurring oxysterols. Cell Biol Toxicol 17, 127-137.

Palmer HJ \& Paulson KE (1997) Reactive oxygen species and antioxidants in signal transduction and gene expression. Nutr Rev 55, 353-361.

Robinson JP, Carter WO \& Narayanan PK (1994) Oxidative product formation analysis by flow cytometry. Methods Cell Biol 41, 437-447.

Sprecher H, Barr HM, Slotky JI, Tzukerman M, Eytan GD \& Assaraf YG (1995) Alteration of mitochondrial gene expression and disruption of respiratory function by the lipophilic antifolate pyrrimethamine in mammalian cells. J Biol Chem 270, 20668-20676.

Stridh H, Kimland M, Jones DP, Orrenius S \& Hampton MB (1998) Cytochrome $c$ release and caspase activation in hydrogen peroxide- and tributyltin-induced apoptosis. FEBS Lett 429, 351-355.

Tada-Oikawa S, Oikawa S, Kawanishi M, Yamada M \& Kawanishi S (1999) Generation of hydrogen peroxide precedes loss of mitochondrial membrane potential during DNA alkylation-induced apoptosis. FEBS Lett 442, 65-69.

Title LM, Cummings PM, Giddens K, Genest JJ Jr \& Nassar BA (2000) Effect of folic acid and antioxidant vitamins on endothelial dysfunction in patients with coronary artery disease. $J$ Am Coll Cardiol 36, 758-765.

Zamzami N \& Kroemer G (2001) The mitochondrion in apoptosis: how Pandora's box opens. Nat Rev Mol Cell Biol 2, 67-71. 